\title{
Journey into America: The Challenge of Islam
}

\section{Akbar Ahmed}

Washington, DC: Brookings Institution Press, 2010. hbk. 528 pages

Akbar Ahmed's latest book, Journey into America: The Challenge of Islam, has become one of the first comprehensive ethnographic studies of the Muslim community in America. Ahmed and his team of young researchers offer a keen anthropological analysis of American Muslims that spans over seventy-five cities, one hundred mosques, and two thousand interviews. A modern-day version of Alexis de Tocqueville's Democracy in America, Journey into America charts the various historical, social, and ideological trajectories that have shaped both American and Muslim identities. As such, the work represents one of the first post-9/11 sociological commentaries that attempt to define the nature of American Muslim identity and the possibilities for its reevaluation. Over the course of nine chapters, Ahmed lays out for a general audience the groundwork for precisely such an endeavor.

In the introduction, Ahmed is clear that one cannot study what America means to Muslims without first coming to understand how it is that America and Americans have grappled with Islam. This premise serves as the foundation for the sequential analysis of identity that follows in the rest of the book. The author examines American identity and its formation through an exploration of the historical episodes, which have shaped the distinctive ideological strains that form it; the ethnography of Islam in America and the issues facing native and immigrant Muslim populations in America-as well as the sociocultural factors leading to the conversion 
of white and Latino Americans to Islam - and finally, Ahmed offers a comparison of Muslims to other minority groups in the United States, including Jews and Mormons and the ways each group has adjusted to the presence of the other. Being one of the only complete guides to the American Muslim community, Ahmed does not shy away from more sensitive topicsincluding the persecution of Muslims, terrorism, and its homegrown US variant.

The first section of the book, "American Identity," which opens with chapter 2, presents Ahmed's main theoretical contribution, namely a Weberian ideal type characterization of the three identities that define American society: primordial, pluralist, and predator. Primordial identity is rooted in the landing at Plymouth and is based on the early settlers' aim of building a Christian society. Pluralist and predator identities developed from primordialism, but each are diametrically opposed to one another. Pluralism subscribes to the belief in civil rights and liberties, religious freedom, and tolerance - values that defined the practices of the founding fatherswhile predator identity developed in the face of increasing nationalist zeal, which found its earliest proponents in the seventeenth century colonists who "preyed on natives in the name of protecting the community" (45). The author describes these three strains of American identity by judiciously structuring his argument around the key figures such as Thomas Jefferson, Roger Williams, Theodore Roosevelt, and John F. Kennedy. Ahmed also describes essential events that helped to shape and broaden American identity -including the immigration of the Scots from Ireland, the passage of the Immigration and Nationality Act of 1965 that jumpstarted Muslim immigration, and the terrorist attacks of September 11, 2001. And yet, Ahmed's attempt to reduce American identity into a trichotomy of ideal types becomes problematic when he presents the ethnography to support his argument. While the author concedes that these three identities often overlap and do not serve as a substitute for reality, the qualitative data only serves to reinforce the idea that these identities are, in fact, indisputable. Ahmed casts aside the evidence of the shades of gray that can and must inform any ideal type in favor of a more polarizing depiction of American identity and its struggle to come to terms with its Muslim component.

The second part of the book, "Islam in America," which constitutes chapters 4 through 6 , is by far the most stimulating and informative. Following through with his earlier discussion on how a minority community can maintain its unique identity amid a dominant unifying culture, Ahmed provides a rich contextualized narrative of the major Muslim 
groups in America: African-American, immigrant, and converts. Through interviews with imams, sheikhs, members of the Nation of Islam, Muslim members of Congress, and ordinary men and women, the author locates a wide gamut of individual perspectives regarding Islam-ranging from views about the religion as a "simple and functional way of life" (214), to those that relate to it as a "complex, grand, overarching historical experience" (214), to notions that embrace it as an antidote to the excessive freedoms found in America. And it is this precise juxtaposition of religious sentiments that gives Ahmed's discussion of American Islam its empirical clout. Ahmed goes beyond clichéd comparisons of Muslims to nonMuslims to offer an intimate portrait of how Muslims relate to one another and how their positionality within America informs their views. However, at the same time, Ahmed's depiction of Islam and Muslims succumbs to the same reductionism inherent in his portrayal of American identity. By distinguishing among three traditions - mystic (belief in universal humanism), modernist (balance between modernity and religion), and literalist (strict adherence to tradition) - found in the immigrant Muslim community, Ahmed provides a much too simplified representation of this group that is ill-equipped at capturing nuanced intra-group variations in values, beliefs, and practices. While a tripartite division of Muslim identity provides the author with the theoretical leverage necessary to draw parallels with primordial, pluralist, and predator identities, it does so at the cost of greater empirical refinement.

The third and final section of the book, "Adjusting and Adapting," which encompasses chapters 7 through 9, offers an engaging description of other minority groups - namely Jews and Mormons - and the ways that each has come to understand and relate to their Muslim counterparts. Here, Ahmed's discussion of pluralism and integration comes full circle, as he draws sociohistorical parallels among these groups. By discussing shared histories of persecution, cultural practices, doctrinal beliefs, and coping strategies for maintaining religious and cultural practices in the face of a dominant centralizing culture, Ahmed unfolds a narrative that eloquently ties together his earlier points about boundaries, positionality, and the limits of American pluralism. In the last chapter, the author lays out a framework for mutual understanding by drawing similarities between two founding fathers: Thomas Jefferson and Mohammed Ali Jinnah, who embodied American and Pakistani pluralism, respectively. This comparison becomes the touchstone by which Ahmed measures the extent to which America, as a whole, needs to go in order to reach the pluralistic ideals set 
by these men. The author sketches out a series of policy recommendations that provides a practical approach by which integration and pluralism can be conceived in contemporary America.

The book provides a well-researched and engaging glimpse into American society. Written by a distinguished scholar and diplomat, it offers one of the first ethnographic accounts of America from a Muslim perspective. Journey into America is the first to place a mirror in front of both Muslims and non-Muslims alike and reflects realities that they themselves may not be ready to confront. And yet, notwithstanding this, Ahmed's mirror sacrifices nuance in favor of greater ethnographic scope. As such, the book remains a preliminary odyssey into the heart of America and American Muslims. Nevertheless, Ahmed has accomplished what few others have been unable to do. Namely, he has pushed us to come face to face with our own knowledge about ourselves, our compatriots, and our subjectivitiesperhaps this journey's ultimate lesson. 